\title{
EFFECT OF CONSTANT TEMPERATURE DEGREES ON CERTAIN BIOLOGICAL CHARACTERSTICS OF THE COCCINELLID PREDATOR Rodolia cardinalis (MULSANT) (COLEOPTERA: COCCINELLIDAE) \\ Mohamed, Nadia E. \\ Plant Protection Research Institute, Agricultural Research Center, Dokki, Giza, Egypt.
}

\begin{abstract}
Laboratory experiments were carried out in the Insectary of Economic Entomology Department Faculty, of Agriculture, Mansoura University, from the beginning of October 2011 tell the end of September 2012 under three constant temperature degrees $\left(15 \pm 1,25 \pm 1\right.$ and $\left.30 \pm 1 \mathrm{C}^{0}\right)$ to study the influence of three constant temperature degrees on biological characteristics for the coccinellid predator Rodolia cardinalis (Mulsant) when reared on the third nymphal instars of Icerya purchasi Mask. The obtained results revealed that, the average of the total consumption per larva was $55.96 \pm 1.3$ individuals, the duration period of the larval stage averaged $30.1 \pm 0.56$ days. The percentages of the mortality were $20.5,13.9,6.9$ and $5.6 \%$ during the four larval instars respectively when this predator reared on $I$. purchasi under constant temperature of $15 \pm 1 \mathrm{C}^{\circ}$ and $70 \pm 5 \%$. The predator female fed on a total average of $389.28 \pm 5.7$ individuals, during the longevity period of $66.07 \pm 3.7$ days. The number of deposited eggs per predator female was averaged $156 \pm 3.9$ eggs. The predator male consumed a total average of $210.75 \pm 3.42$ individuals. Meanwhile the data showed that, the average of the total consumption per larva was $107.53 \pm 6.2$ individuals, when this predator reared on $I$. purchasi nymphs under constant temperature of $25 \pm 1 \mathrm{C}^{\circ}$ and $70 \pm 5 \%$, the duration period of the larval stage averaged $14.37 \pm 1.6$ days. The percentages of the mortality were $13.4,9.1,4.5$ and $3.7 \% \%$ during the four larval instars respectively. The predator female fed on a total average of $348.82 \pm 8.56$ individuals, during the longevity period of $42.5 \pm 2.1$ days. The number of deposited eggs per predator female was averaged $455.79 \pm 10.17$ eggs. The predator male consumed a total average of $201.74 \pm 5.96$ individuals. The obtained results revealed that, the average of the total consumption per larva was $87.16 \pm 4.6$ individuals, the duration period of the larval stage averaged $9.24 \pm 1.95$ days. The percentages of the mortality were 14.2, 10.4, 5.7 and $4.5 \%$ during the four larval instars respectively when this predator reared on $I$. purchasi under constant temperature of $30 \pm 1 \mathrm{C}^{\circ}$ and $70 \pm 5 \%$. The predator female fed on a total average of $248.30 \pm 7.96$ individuals, during the longevity period of $32.15 \pm 1.92$ days. The number of deposited eggs per predator female was averaged $310.75 \pm 8.56$ eggs. The predator male consumed a total average of $176.35 \pm 5.46$ individuals. Statistical analysis showed significant differences between the duration periods as well as the average of total consumption per larvae for the larval stage under the three constant temperature degrees. Meanwhile the statistical analysis cleared significant differences between the longevity period for female and male as well as the average of total consumption and the number of deposited eggs per female and the three constant temperature degrees. In conclusion the optimum temperature for mass rearing of this predator was $25 \pm 1 \mathrm{C}^{\circ}$ because the number of deposited eggs per female the feeding capacity was the highest in comparison with the other temperature degrees.
\end{abstract}

Keywords: Rodolia cardinalis (Mulsant); Icerya purchasi Mask; constant temperature; Biology. 


\section{INTRODUCTION}

Coccinellid predator is potentially important predatory insects found throughout the world on many economic crops. Certain species may have a significant role in biological control of aphid species, whiteflies and other soft bodied insects. $R$. cardinalis (Coleoptera: Coccinellidae) is an important Coccinellid predator feeding on mealybug species (Hamed and Saad, 1989; Lehane 1998; Ibrahim 2005; Ghanim et al. 2006 and Awadalla 2010). The effect of temperature degrees and mealybug species as preys on the developmental time, fecundity and other biological aspects were studied by several investigators in different part of the world (Khalaf 1987; Ragab 1995; Cuaston et al. 2004; Grafton et al. 2005; Ghanim et al. 2006; Awadalla 2010 and Abdel-Salam et al. 2013). In Egypt little information is available on the influence of different constant temperature degrees on the biological characteristics and life table parameters of the most important predators feeding on mealybug species. However, scanty attention has been paid to the developmental time and feeding capacity and fecundity of the female to measure these parameters for mass rearing and release. Therefore the objective of this study was aimed to study the influence of three constant temperature degrees on biological characteristics for the coccinellid predator R. cardinalis.

\section{MATERIALS AND METHODS}

Laboratory experiments were carried out in the Insectary of Economic Entomology Department Faculty, of Agriculture, Mansoura University, from the beginning of October 2011 tell the end September 2012 under three constant temperature degrees $(15 \pm 1,25 \pm 1$ and $30 \pm 1)$. To obtain a culture from Rodolia cardinalis (Mulsant) a large number of this predator in the pupal stage were collected from ficus, Ficus nitida Thunb., guava trees, Psidium guajava L. and citrus trees which were found to be a heavily infested with Icerya purchasi Mask and transferred to Laboratory until emergence of the adults. Newly deposited eggs of this predator was divided into three group; each group consisted of 50 eggs each group of the eggs was kept at one of the following constant temperature degrees $15 \pm 1,25 \pm 1$ and $30 \pm 1$ as well as $70 \pm 5 \%$ R. H.

\section{A: Larval experiments}

To avoid cannibalism, newly first larval instar of the predator from each group were individually in Petri dishes $(10 \mathrm{~cm}$ diameters) and divided to three groups consisted of 20 larvae was use as a replicate and fed on $I$. purchasi nymphs. Apiece of filter paper was placed on the bottom of each Petri dish to provide a walking surface for the predator larvae. A known surplus numbers of the third nymph instar of I. purchasi species were offered and the devoured individuals were replaced daily for $R$. cardinalis. A small leaves from ficus or guava replaced daily as a food for the third nymphal instar of this mealybug species. Attached prey individuals were counted and recorded daily throughout the period of the larval instars. 


\section{B.: Adult experiments}

After emergence from the pupae the predator adults were sexed and then introduced singly into a Petri dish. Know numbers of $I$. purchasi nymphs were offered daily on a ficus or guava leaflet to predator adults. Counting and removing the un- devoured nymphs in Petri dish were practiced before introducing the new nymph individuals. After five or six days of emergence copulation took place and the two sexes were immediately separated and kept singly in the dishes. Daily numbers of laid eggs per predator female during its ovipositional period was counted. In addition the total number of eggs laid per predator female was estimated. The daily consumption throughout adult was calculated.

\section{C: Data analysis}

Data for the developmental time and average of consumption per larval stage longevity, fecundity and consumption rate of the $R$. cardinalis adult when reared on I. purchasi nymphs were subject for one way analysis of variance (Anova) and the means were separated using Dancan's Multiple Rang Test (Cohrot Software 2004)

\section{RESULTS AND DISCUSSION}

\section{I: Rodolia cardinalis reared on I. purchasi nymphs under constant temperature of $15 \pm 1 \mathrm{C}^{\circ}$ and $70 \pm 5$ R.H. \\ A: Larval stage}

Data represented in Table (1) showed the duration period, food consumption and mortality percentages of the larval stage when reared on the third nymphal instar of $l$. purchasi and constant temperature of $15 \pm 1 \mathrm{C}^{\circ}$ and $70 \pm 5$ relative humidity. It can be seen from this table that, the duration period of the larval stage averaged $30.1 \pm 0.56$ days. The average of the total consumption during the four larval instars was $8.56 \pm 0.4,8.78 \pm 0.43$, $16.86 \pm 0.52$ and $21.76 \pm 0.8$ individual respectively. Meanwhile, the results revealed that, the average of the total consumption per larva was $55.96 \pm 1.3$ individuals. The percentages of feeding capacity for each of the four larval instars of this predator were 15.3, 15.69, 30.13 and $38.88 \%$ respectively. Therefore, it is obvious that, the third and fourth larval instar of this predator represent together $69.01 \%$ or backbone in the predation activity. The percentages of the mortality were $20.5,13.9,6.9$ and $5.6 \%$ during the four larval instars respectively.

Awadalla (2010) indicated that the total developmental times of the immature stages for $R$. cardinalis were $62.30,41.10,26.85,18.85$ and 12.7 days with significant differences when reared on I. purchasi at 16, 20, 24, 28 and $32 \mathbf{C}^{\circ}$ respectively. Abdel-Salam et al. (2013) recorded that the average of developmental time of the larval stage lasted $29.65 \pm 0.95$ days when reared I. purchasi nymphs and reared under $16 \mathrm{C}^{\circ}$ and $60 \pm 5 \% \mathrm{R}$. H. 
Table (1): Duration period, predaceous efficiency and percentage of mortality of $\boldsymbol{R}$. cardinalis reared on $\boldsymbol{I}$. purchasi nymphs under constant temperature of $15 \pm 1 \mathrm{C}^{\circ}$ and $70 \pm 5 \%$ relative humidity.

\begin{tabular}{|l|c|c|c|c|c|}
\hline Larval stage & $\begin{array}{c}\text { Duration in } \\
\text { days }\end{array}$ & $\begin{array}{c}\text { Daily average } \\
\text { consumption }\end{array}$ & $\begin{array}{c}\text { Average of } \\
\text { total } \\
\text { consumption }\end{array}$ & $\begin{array}{c}\% \text { of } \\
\text { feeding } \\
\text { capacity }\end{array}$ & $\begin{array}{c}\% \text { of } \\
\text { Mortality }\end{array}$ \\
\hline $\mathbf{1}^{\mathbf{s t}}$ instar & $8.8 \pm 0.17$ & 0.97 & $8.56 \pm 0.4$ & 15.3 & 20.5 \\
\hline $\mathbf{2}^{\text {nd }}$ instar & $6.9 \pm 0.26$ & 1.27 & $8.78 \pm .43$ & 15.69 & 13.9 \\
\hline $\mathbf{3}^{\text {rd }}$ instar & $5.8 \pm 0.32$ & 2.9 & $16.86 \pm 0.52$ & 30.13 & 6.9 \\
\hline $\mathbf{4}^{\text {th }}$ instar & $8.6 \pm 0.39$ & 2.53 & $21.76 \pm 0.8$ & 38.88 & 5.6 \\
\hline Total & $30.1 \pm 0.56$ & 1.86 & $55.96 \pm 1.3$ & 100 & \\
\hline
\end{tabular}

\section{B: Adult stage}

\section{1: Predator female}

The predator female fed on a total average of $389.28 \pm 5.7$ individuals, with a daily rate of 5.89 individuals during the longevity period of $66.07 \pm 3.7$ days as seen in Table (2). The average of the pre-oviposition period was $10.46 \pm 0.75$ days. The predator female consumed during this period 76.96 individuals with a daily rate of 7.35 individuals. The predator female consumed during the ovipasition period on an average of $256.47 \pm 3.76$ individuals, this period lasted an average of $38.75 \pm 1.86$ days with a daily rate of 6.62 individual's. The number of deposited eggs per predator female averaged $156 \pm 3.9$ eggs with a daily rate 4.03 eggs per day. During the postoviposition period, the predator female consumed $55.85 \pm 2.15$ individuals this period lasted an average of $16.86 \pm 0.96$ days with a daily rate of 3.31 individuals.

\section{2: Predator male}

During its longevity, was lasted for an average of $45.96 \pm 2.4$ day's Table (2). The predator male consumed a total average of $210.75 \pm 3.42$ individuals with daily rate of 4.58 individuals.

Table (2): Longevity, food consumption and fecundity of $\boldsymbol{R}$. cardinalis adult reared on the third nymphal instars of $I$. purchasi under constant temperature of $15 \pm 1 \mathrm{C}^{\circ}$ and $70 \pm 5 \%$ relative humidity.

\begin{tabular}{|c|c|c|c|c|c|}
\hline \multirow{2}{*}{ Adult stage } & \multirow{2}{*}{ Period in days } & \multirow{2}{*}{$\begin{array}{l}\text { Daily average } \\
\text { consumption }\end{array}$} & \multirow{2}{*}{$\begin{array}{c}\text { Average of } \\
\text { total } \\
\text { consumption }\end{array}$} & \multicolumn{2}{|c|}{ No. of eggs } \\
\hline & & & & Daily & Total \\
\hline \begin{tabular}{|l|} 
A : Female \\
Pre-oviposition \\
Oviposition \\
Post-oviposition \\
Longevity
\end{tabular} & $\begin{array}{c}10.46 \pm 0.75 \\
38.75 \pm 1.86 \\
16.86 \pm 0.96 \\
66.07 \pm 3.7\end{array}$ & $\begin{array}{l}7.35 \\
6.62 \\
3.31 \\
5.89\end{array}$ & $\begin{array}{c}76.96 \pm 1.96 \\
256.47 \pm 3.76 \\
55.85 \pm 2.15 \\
389.28 \pm 5.7\end{array}$ & 4.03 & $156 \pm 3.9$ \\
\hline $\begin{array}{l}\text { B : Male } \\
\text { Longevity }\end{array}$ & $45.96 \pm 2.4$ & 4.58 & $210.75 \pm 3.42$ & & \\
\hline
\end{tabular}


II: Rodolia cardinalis reared on I. purchasi nymphs under constant temperature of $25 \pm 1 \mathrm{C}^{\circ}$ and $70 \pm 5$ R.H.

\section{A: Larval stage}

Data represented in Table (3) revealed that the duration period, food consumption and mortality percentages on the third nymphal instar of $l$. purchasi and constant temperature of $25 \pm 1 \mathrm{C}^{\circ}$. It can be seen from this table that, the duration period of the larval stage averaged $14.37 \pm 1.6$ days. The average of the total consumption during the four larval instars were $13.12 \pm 0.90,15.72 \pm 1.2,20.89 \pm 2.53$ and $57.80 \pm 3.21$ individual, respectively. Meanwhile, the results revealed that, the average of the total consumption per larva was $107.53 \pm 6.2$ individuals. The percentages of feeding capacity for each of the four larval instars of this predator were 12.2, 14.62, 19.43 and $53.75 \%$ respectively. Therefore, it is obvious that, the third and fourth larval instar of this predator represent together $73.18 \%$ or backbone in the predation activity. The percentages of the mortality were 13.4, 9.1, 4.5 and $3.7 \%$ during the four larval instars respectively.

Table (3): Duration period, predaceous efficiency and percentage of mortality of $\boldsymbol{R}$. cardinalis reared on $I$. purchasi nymphs under constant temperature of $25 \pm 1 \mathrm{C}^{\circ}$ and $70 \pm 5 \%$ relative humidity.

\begin{tabular}{|l|c|c|c|c|c|}
\hline $\begin{array}{c}\text { Larval } \\
\text { stage }\end{array}$ & $\begin{array}{c}\text { Duration in } \\
\text { days }\end{array}$ & $\begin{array}{c}\text { Daily average } \\
\text { consumption }\end{array}$ & $\begin{array}{c}\text { Average of } \\
\text { total } \\
\text { consumption }\end{array}$ & $\begin{array}{c}\% \text { of feeding } \\
\text { capacity }\end{array}$ & $\begin{array}{c}\% \text { of } \\
\text { Mortality }\end{array}$ \\
\hline $\mathbf{1}^{\text {st }}$ & $3.82 \pm 0.36$ & 3.43 & $13.12 \pm 0.90$ & 12.20 & 13.4 \\
\hline $\mathbf{2}^{\text {nd }}$ & $2.91 \pm 0.17$ & 5.40 & $15.72 \pm 1.20$ & 14.62 & 9.1 \\
\hline $\mathbf{3}^{\text {rd }}$ & $2.53 \pm 0.12$ & 8.26 & $20.89 \pm 2.53$ & 19.43 & 4.5 \\
\hline $\mathbf{4}^{\text {th }}$ & $5.11 \pm 0.85$ & 11.31 & $57.80 \pm 3.21$ & 53.75 & 3.7 \\
\hline Total & $14.37 \pm 1.6$ & 7.48 & $107.53 \pm 6.2$ & 100 & \\
\hline
\end{tabular}

Ibrahim (2005) added that the temperature threshold for egg stage, first, second, third and four larval instars and pupal stage were 10.67, 9.23, $9.60,9.84,11$ and $10.74 \mathrm{C}^{\circ}$ respectively.

\section{B: Adult stage}

\section{1: Predator female}

The predator female fed on a total average of $348.82 \pm 8.56$ individuals, with a daily rate of 8.21 individuals during the longevity period of $42.5 \pm 2.1$ days as seen in Table (4). The average of the pre-oviposition period was $5.42 \pm 0.32$ days. The predator female consumed during this period $49.78 \pm 1.3$ individuals with a daily rate of 9.18 individuals. The predator female consumed during the ovipasition period on an average of 263.75 6.4 individuals, this period lasted an average of $30.85 \pm 1.36$ days with a daily rate of 8.55 individual's. The number of deposited eggs per predator female averaged $455.79 \pm 10.17$ eggs with a daily rate 14.77 eggs. During the postoviposition period, the predator female consumed $35.29 \pm 1.1$ individuals this period lasted an average of $6.23 \pm 0$. 5 days with a daily rate of 5.66 individuals. 


\section{2: Predator male}

During its longevity, which was lasted for an average of $28.57 \pm 1.94$ day's table (4). The predator male consumed a total average of $201.74 \pm 5.96$ individuals with daily rate of 7.06 individuals.

Table (4): Longevity, food consumption and fecundity of $\boldsymbol{R}$. cardinalis adult reared on the third nymphal instars of $I$. purchasi under constant temperature of $25 \pm 1 \mathrm{C}^{\circ}$ and $70 \pm 5 \%$ relative humidity.

\begin{tabular}{|c|c|c|c|c|c|}
\hline \multirow{2}{*}{ Adult stage } & \multirow{2}{*}{$\begin{array}{l}\text { Period in } \\
\text { days }\end{array}$} & \multirow{2}{*}{$\begin{array}{l}\text { Daily average } \\
\text { consumption }\end{array}$} & \multirow{2}{*}{$\begin{array}{c}\text { Average of } \\
\text { total } \\
\text { consumption }\end{array}$} & \multicolumn{2}{|c|}{ No. of eggs } \\
\hline & & & & Daily & Total \\
\hline \begin{tabular}{|l|} 
A : Female \\
Pre-oviposition \\
Oviposition \\
Post- \\
oviposition \\
Longevity \\
\end{tabular} & $\begin{array}{c}5.42 \pm 0.32 \\
30.85 \pm 1.36 \\
6.23 \pm 0.5 \\
42.5 \pm 2.1 \\
\end{array}$ & $\begin{array}{l}9.18 \\
8.55 \\
5.66 \\
\\
8.21 \\
\end{array}$ & $\begin{array}{c}49.78 \pm 1.30 \\
263.75 \pm 6.4 \\
35.29 \pm 1.1 \\
348.82 \pm 8.56 \\
\end{array}$ & 14.77 & $455.79 \pm 10.17$ \\
\hline $\begin{array}{l}\text { B : Male } \\
\text { Longevity }\end{array}$ & $28.57 \pm 1.94$ & 7.06 & $201.74 \pm 5.96$ & & \\
\hline
\end{tabular}

Matsuka and Watanabe (1981) indicated that adult females of vedalia beetles which fed on adults of Icerya scales in Petri dish at $25 \mathrm{C}^{\circ}$ produce an average of 365 eggs during their life spain of 29.4 days. Awadalla (2010) mentioned that the fecundity rate were significantly higher at $28 \mathbf{C}^{\circ}$ than that at $24,32,20$ and $16 \mathbf{C}^{\circ}$ when fed on the third nymphal instar of I. purchasi, I. aegyptiaca and $I$. seychellarum

III: Rodolia cardinalis reared on I. purchasi nymphs under constant temperature of $30 \mathrm{C}^{\circ}$.

\section{A: Larval stage}

Data represented in Table (5) indicated the duration period, food consumption and mortality percentages of the larval stage of $R$. cardinalis under constant temperature of $30 \pm 1 \mathrm{C}^{\circ}$ and $70 \pm 5 \%$ relative humidity. It can be seen from this table that, the duration period of the larval stage averaged $9.24 \pm 1.95$ days. The average of the total consumption during the four larval instars was $10.78 \pm 1.2,13.54 \pm 1.53,17.26 \pm 1.82$ and $45.58 \pm 2.1$ individuals respectively. Meanwhile, the results revealed that, the average of the total consumption per larvae was $87.16 \pm 4.6$ individuals. The percentages of feeding capacity for each of the four larval instars of this predator were 12.37, 15.53, 19.8 and $52.3 \%$ respectively. Therefore, it is obvious that, the third and fourth instar larvae of this predator represent together $72.1 \%$ or backbone in the predation activity. The percentages of the mortality were $14.2,10.4,5.7$ and $4.5 \%$ during the four larval instars respectively. 
Table (5): Duration period, predaceous efficiency and percentage of mortality of $\boldsymbol{R}$. cardinalis reared on $I$. purchasi nymphs under constant temperature of $30 \mathrm{C}^{\circ}$ and $70 \pm 5 \%$ relative humidity.

\begin{tabular}{|l|c|c|c|c|c|}
\hline $\begin{array}{c}\text { Larval } \\
\text { stage }\end{array}$ & $\begin{array}{c}\text { Duration in } \\
\text { days }\end{array}$ & $\begin{array}{c}\text { Daily average } \\
\text { consumption }\end{array}$ & $\begin{array}{c}\text { Average of total } \\
\text { consumption }\end{array}$ & $\begin{array}{c}\% \text { of } \\
\text { feeding } \\
\text { capacity }\end{array}$ & $\begin{array}{c}\% \text { of } \\
\text { Mortality }\end{array}$ \\
\hline $\mathbf{1}^{\text {st }}$ & $2.87 \pm 0.26$ & 3.76 & $10.78 \pm 1.2$ & 12.37 & 14.2 \\
\hline $\mathbf{2}^{\text {nd }}$ & $1.70 \pm 0.19$ & 7.96 & $13.54 \pm 1.53$ & 15.53 & 10.40 \\
\hline $\mathbf{3}^{\text {rd }}$ & $1.52 \pm 0.15$ & 11.36 & $17.26 \pm 1.82$ & 19.8 & 5.70 \\
\hline $\mathbf{4}^{\text {th }}$ & $3.15 \pm 1.7$ & 14.47 & $45.58 \pm 2.1$ & 52.30 & 4.50 \\
\hline Total & $9.24 \pm 1.95$ & 9.43 & $87.16 \pm 4.6$ & 100 & \\
\hline
\end{tabular}

Awadalla (2010) indicated that the duration period for the larval stage of $R$. cadinalis was lasted $5.9 \pm 0.33$ days where reared on $I$. purchasi nymphs under constant temperature of $32 \mathrm{C}^{\circ}$ and $60 \pm 5 \% \mathrm{R}$. $\mathrm{H}$.

\section{B: Adult stage}

\section{1: Predator female}

The predator female fed on a total average of $248.3 \pm 7.96$ individuals, with a daily rate of 7.72 individuals during the longevity period of $32.15 \pm 1.92$ days as seen in table (6). The average of the pre-oviposition period was $4.2 \pm 0.5$ days. The predator female consumed during this period $33.78 \pm 2.6$ individuals with a daily rate of 8.04 . The predator female consumed during the ovipasition period on an average of $185.56 \pm 4.78$ individuals, this period lasted an average of $22.19 \pm 1.37$ days with a daily rate of 8.36 individuals. The number of deposited eggs per predator female averaged $310.75 \pm 8.56$ eggs with a daily rate 14.0 eggs per daily. During the post-oviposition period, the predator female consumed $28.96 \pm 5.36$ individuals this period lasted an average of $5.76 \pm 0.65$ days with a daily rate of 5.02 individuals.

\section{2: Predator male}

During its longevity, which was lasted for an average of $23.92 \pm 1.42$ days the predator male consumed a total average of $176.35 \pm 5.46$ individuals with daily rate of 7.37 individuals Table (6).

Table (6): Longevity, food consumption and fecundity of $\boldsymbol{R}$. cardinalis adult reared on the third instars of $I$. purchasi under constant temperature of $30 \mathrm{C}^{\circ}$ and $70 \pm 5 \%$ relative humidity.

\begin{tabular}{|c|c|c|c|c|c|}
\hline \multirow{2}{*}{ Adult stage } & \multirow{2}{*}{$\begin{array}{l}\text { Period in } \\
\text { days }\end{array}$} & \multirow{2}{*}{$\begin{array}{l}\text { Daily average } \\
\text { consumption }\end{array}$} & \multirow{2}{*}{$\begin{array}{c}\begin{array}{c}\text { Average of } \\
\text { total } \\
\text { consumption }\end{array} \\
\end{array}$} & \multicolumn{2}{|c|}{ No. of eggs } \\
\hline & & & & Daily & Total \\
\hline $\begin{array}{l}\text { A : Female } \\
\text { Pre-oviposition } \\
\text { Oviposition } \\
\text { Post-oviposition } \\
\text { Longevity }\end{array}$ & $\begin{array}{c}4.20 \pm 0.5 \\
22.19 \pm 1.37 \\
5.76 \pm 0.65 \\
32.15 \pm 1.92\end{array}$ & $\begin{array}{l}8.04 \\
8.36 \\
5.02 \\
7.72 \\
\end{array}$ & $\begin{array}{c}33.78 \pm 2.6 \\
185.56 \pm 4.78 \\
28.96 \pm 5.36 \\
248.30 \pm 7.96\end{array}$ & 14.0 & $310.75 \pm 8.56$ \\
\hline $\begin{array}{l}\text { B : Male } \\
\text { Longevity }\end{array}$ & $23.92 \pm 1.42$ & 7.37 & $176.35 \pm 5.46$ & & \\
\hline
\end{tabular}


Hamed and Chemsedine (2001) noticed that the fecundity of females at different temperatures ranged between 107 eggs at $15 \mathrm{C}^{\circ}$ and 601.86 eggs at $30 \mathrm{C}^{\circ}$. The pre-oviposition period ranged between 23.75 days at $15 \mathrm{C}^{\circ}$ and 3.47 at $35 \mathrm{C}^{\circ}$. Abdel-Salam (2013) found that the fecundity of $R$. cardinalis females was $336.6 \pm 25.43$ eggs per female when reared I. aegyptiaca nymphs under constant temperature of 28 and $70 \pm 5$ R.H.

The obtained result in Table (7) cleared that the duration period and average of total consumption per larva of $R$. cardinalis when fed on $I$. purchasi nymphs under different constant temperature of 15,25 and $30 \mathrm{C}^{\circ}$ lasted $30.1 \pm 0.56 ; 14.37 \pm 1.6$ and $9.24 \pm 1.95$ respectively. Also the average of the total consumption per larva was $55.96 \pm 1.3,107.53 \pm 6.2$ and $87.16 \pm 4.6$ individual respectively. Statistical analysis showed significant differences between the duration period as well as the average of total consumption per larvae for the larval stage under the three constant temperature degrees.

Table (7) Influence of three constant temperature degrees on duration period of the larval stage and predaceous efficiency of $R$. cardinalis reared on third nymphal instar of $I$. purchasi

\begin{tabular}{|l|c|c|}
\hline Biol. aspects & Duration in days & $\begin{array}{c}\text { Average of total } \\
\text { consumption }\end{array}$ \\
\hline Temp. degree & $30.1 \pm 0.56 \mathrm{a}$ & $55.96 \pm 1.3 \mathrm{c}$ \\
\hline $\mathbf{1 5} \mathbf{C}^{\circ}$ & $14.37 \pm 1.6 \mathrm{~b}$ & $107.53 \pm 6.2 \mathrm{a}$ \\
\hline $\mathbf{2 5} \mathbf{C}^{\mathbf{0}}$ & $9.24 \pm 1.95 \mathrm{C}$ & $87.16 \pm 4.6 \mathrm{~b}$ \\
\hline $\mathbf{3 0} \mathbf{C}^{\circ}$ & & \\
\hline
\end{tabular}

Mean followed by the same letters in a column for each period are not significantly differences at $\mathbf{0 . 0 5 l e v e l ~ o f ~ p r o b a b i l i t y ~ ( D a n c a n ' s ~ M u l t i p l e ~ R a n g e ~ T e s t ) . ~}$

Data illustrated in Table (8) revealed that the longevity; average of total consumption and fecundity per female under the three constant temperature. As a conclusion the average of longevity for female were reached $66.07 \pm 3.7$, $42.5 \pm 2.1$ and $32.15 \pm 1.92$ days and for the male $45.96 \pm 2.4,28.57 \pm 1.98$ and $23.92 \pm 1.42$ under the three constant temperature degrees respectively. Meanwhile the average total consumption per female was $389.28 \pm 8.35$, $348.82 \pm 8.1$ and $284.3 \pm 7.96$ individuals while that was $210 \pm 3.42,201.74 \pm 5.96$ and $176.35 \pm 3.46$ individuals per the male of this predator and the three constant temperatures respectively. The number of deposited eggs per female was $156 \pm 3.9,455.79 \pm 10.17$ and $310.75 \pm 8.56$ under the three constant temperature statistical analysis showed significant differences between the longevity period for female and male as well as the average of total consumption and the number of deposited eggs per female and the three constant temperature degrees. In conclusion the optimum temperature for mass rearing of this predator was $25 \mathrm{C}^{\circ}$ because the number of deposited eggs per female the feeding capacity was the highest in comparison with the other temperature degrees. 
Table (8) Influence of three constant temperature degrees on the longevity; predator efficiency and fecundity of $\boldsymbol{R}$. cardinalis adults reared on the third nymphal instar of $I$. purchasi.

\begin{tabular}{|l|c|c|c|c|c|}
\hline \multirow{2}{*}{ Biol.aspects } & \multicolumn{2}{|c|}{ Longevity } & \multicolumn{2}{c|}{$\begin{array}{c}\text { Average of total } \\
\text { consumption }\end{array}$} & Fecundity \\
\cline { 2 - 6 } Temp. degrea & Female & Male & Female & Male & Female \\
\hline $\mathbf{1 5} \mathbf{C}^{\mathbf{0}}$ & $66.07 \pm$ & $45.96 \pm$ & $389.28 \pm$ & $210 \pm$ & $156 \pm$ \\
& $3.7 \mathrm{a}$ & $2.4 \mathrm{a}$ & $8.35 \mathrm{a}$ & $3.42 \mathrm{a}$ & $3.9 \mathrm{c}$ \\
\hline $\mathbf{2 5} \mathbf{C}^{\mathbf{0}}$ & $42.5 \pm$ & $28.57 \pm$ & $348.82 \pm$ & $201.74 \pm$ & $455.79 \pm$ \\
& $2.1 \mathrm{~b}$ & $1.98 \mathrm{~b}$ & $8.1 \mathrm{~b}$ & $5.96 \mathrm{a}$ & $10.17 \mathrm{a}$ \\
\hline $\mathbf{3 0} \mathbf{C}^{\mathbf{0}}$ & $32.15 \pm$ & $23.92 \pm$ & $284.3 \pm$ & $176.35 \pm$ & $310.75 \pm$ \\
& $1.92 \mathrm{c}$ & $1.42 \mathrm{bc}$ & $7.96 \mathrm{c}$ & $3.46 \mathrm{~b}$ & $8.56 \mathrm{~b}$ \\
\hline
\end{tabular}

Mean followed by the same letters in a column for each period are not significantly differences at $\mathbf{0 . 0 5 l e v e l ~ o f ~ p r o b a b i l i t y ~ ( D a n c a n ' s ~ M u l t i p l e ~ R a n g e ~ T e s t ) . ~}$

The obtained results are in agreement with those by Ibrahim (2005); Grafton et al. (2005); Awadalla (2013) and Abdel-Salam et al. (2013).

\section{REFERENCES}

Abdel-Salam A. H.; A. A. Ghanim; H. A. Elkady ; M. E. El-Nagar and Hager S. S. Awalalla (2013). Influnce of constant temperature degrees on the biological characters and predaceous efficiency of the predator Rodollia cardinalis (Mulsant) J. Plant Prot. and Path. Mansoura Univ., 4(3): 317-324.

Awadalla, Hagar S. S. (2013). Ecological and biological studies on certain mealybug species and thir associated natural enemies at Mansoura district. Ph. D. Thesis, Fac. Agic. Mansoura Univ. pp198.

Awadalla, Hagar S. S. (2010). Studies on biological and life tables parameters of certain predacious insects which associated with some mealybugs. M. Sc. Thesis, Fac. Agric., Mansoura Univ. pp. 125.

Cuaston, C. E.; M. P. Lincango and T. G. A. Poulsom (2004). Feeding range studies of Rodollia cardinalis (Mulsant), a candidate biological control agent of Icerya purchasi Maskell in the Galapagos Islands. Biological control, 29(3): $315-325$.

CoHort Software. (2004). CoStat. Www. cohort. Com. Monterey, California, USA.

Ghanim, A. A : Hala, A. K. EL-Serafi and Nadia, E. Mohamed (2006). Effect of mealybug species as preys on the developmental time, feeding capacity and fecundity of vedalia beetle, Rodolia cardinalis (Mulsant) (Coleoptera: Coccinellidae) under laboratory conditions. J. Agric. Sci. Mansoura Univ., 31 (3): 1679 -1687.

Grafton, E. E.; P. Gu and G. H. Montez (2005). Effect of temperature on development of vedalia beetle, Rodollia cardinalis (Mulsant). Biological control, 32:473 - 478 .

Hamed, A. R. and B. Saad (1989). Adaptation of Rodollia cardinalis (Mulsant) (Coleoptera: Coccinellidae) to Icerya aegyptiaca (Douglas) and Icerya seychellarum (Westwood) (Homoptera: Margrodidae). Proc. First Int. Conf. Econom. Entomol., 11: $33-36$. 


\section{Mohamed, Nadia E.}

Hamed, T and M. Chemsedine (2001). Assessment of temperature effects on the development of vedalia beetle, Rodolia cardinalis (Mulsant). Biological control, 32: 473-478.

Ibrahim, M. M. (2005). Ecological and biological studies on persimmon (Diospyros kaki L.) pests and their natural enemies. Ph. D. Thesis, Fac. Agic. Mansoura Univ. pp 154.

Khalaf, L. (1987). Biological control of Icerya purchasi in Fars. Entomologieet-phytopathologie-Appliquees, 54(2): $123-128$.

Lehane, R. (1998). Breadfruit pest succumbs a ladybird beetle. Parteners in infesting persimmon- a new host record. Tropical-Pest- Management, 38(1): 107-108.

Matsuka, M. and M. Watanabe (1981). Laboratory rearing of vedalia beetles Rodolia cardinalis (Mulsant). Bull. Of the Faculty of Agriculture Tamagawa University, 20:1- 8.

Ragab, M. E. (1995). Adaptation of Rodolia cardinalis (Mulsant) (Coleoptera: Coccinellidae) as compred with Icerya purchasi Mask. J. Appl. Ent., 119(9): $621-633$.

تأثير درجات الحرارة الثابتة على بعض الخصـائص البيولوجيـة لمفترس الفيداليا Rodolia cardinalis (Mulsant) نادية الحسيني محمثل بحثاتية النبات مركز البحوث الزراعية_الدقي- الجيزة- مصر

أجريت تجارب معطلية فى معمل تربية الحشرات بقسم الحشر ات الإقتصادية كلية الزراعة

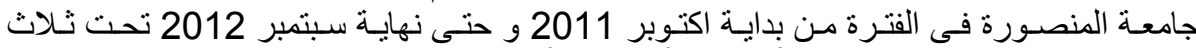

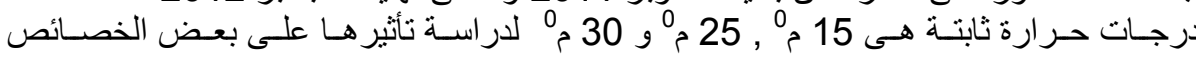

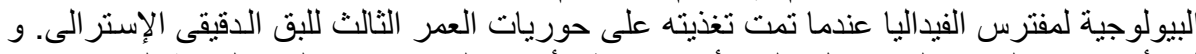

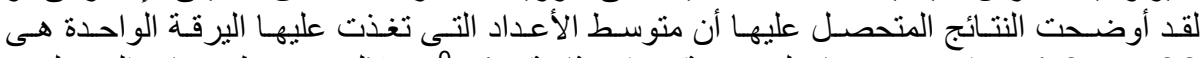

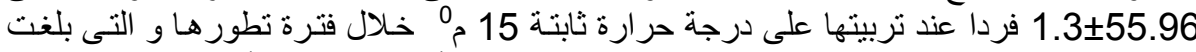

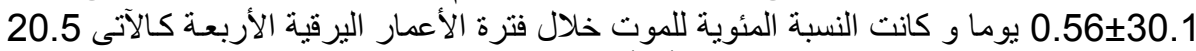

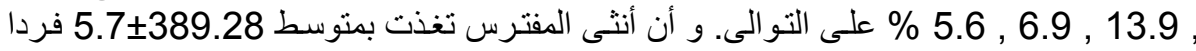

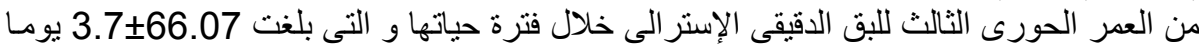

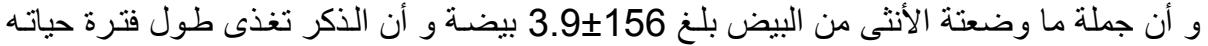

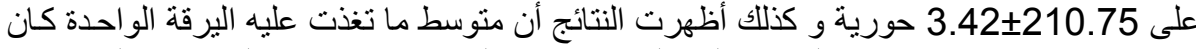

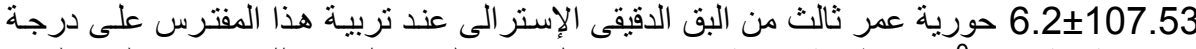

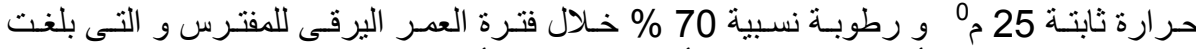

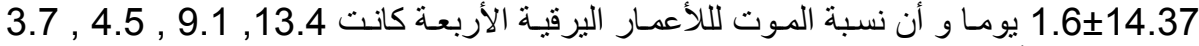

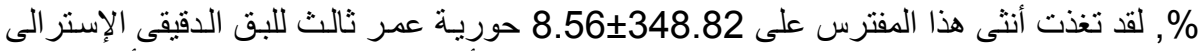

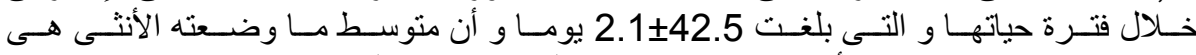

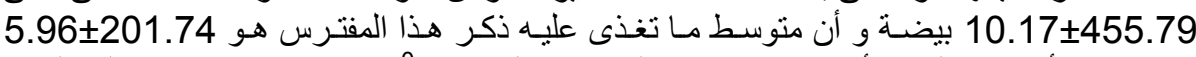

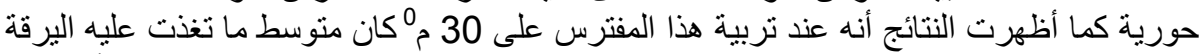

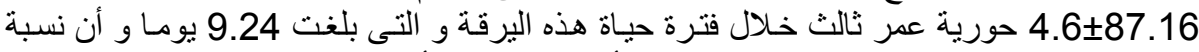

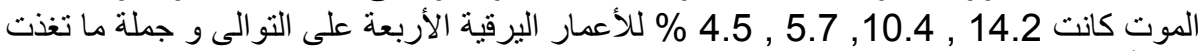

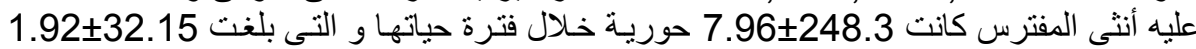




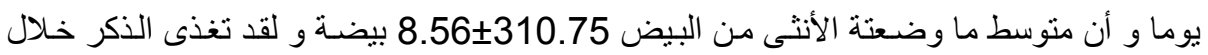

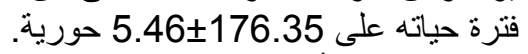

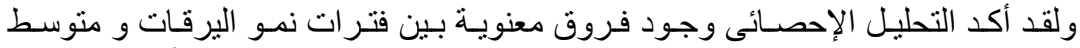

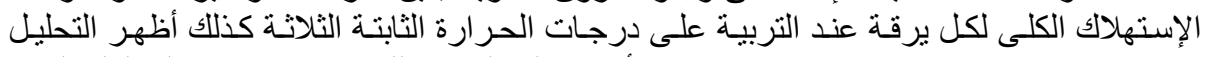

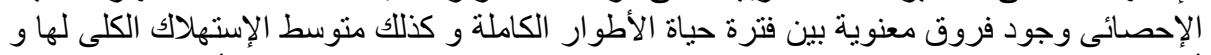

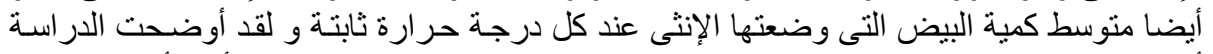

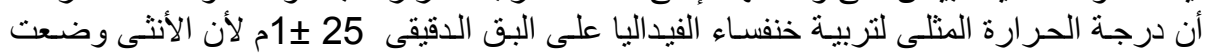

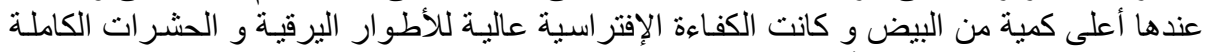

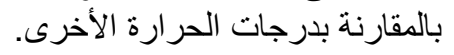

كلية الزراعة - جامعة المنصورة

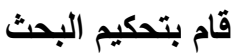
كلية الزراعة - جامعة القاهره

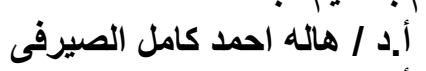

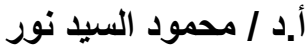

